\title{
Predicting Nuclear Weapons Proliferation
}

\section{Book Chapter}

Author(s):

Schneider, Jonas

Publication date:

2020-05-28

Permanent link:

https://doi.org/10.3929/ethz-b-000424205

Rights / license:

Creative Commons Attribution-NonCommercial-NoDerivatives 4.0 International

Originally published in:

https://doi.org/10.4324/9781003022428-15 


\title{
12 Predicting nuclear weapons proliferation $^{1}$
}

\author{
Jonas Schneider
}

The question of whether the number of states possessing a nuclear weapons arsenal will increase, decline, or remain constant has been an important concern for foreign and defence policy planners throughout the nuclear age. Given the vast destructive power of these weapons and the politico-military benefits they confer (Bell 2015), governments' assessments of what the global nuclear landscape would look like in five or ten years frequently had a strong bearing on how they viewed their nation's future geopolitical position and threat environment. For example, when World War II was drawing to a close, influential US policy-makers believed the American nuclear monopoly would persist for many years. Based on this estimate, they expected a US preponderance of power that would for decades give Washington an ultimate edge over its non-nuclear rivals (Maddock 2010: 22-45). At the other extreme, in the mid-1960s US defence planners anticipated a widespread proliferation of nuclear weapons over the next decade and, as a result, feared that US geopolitical influence might drastically decline (Gavin 2004/05: 104-7, 128-9).

As with other weapons, predicting the proliferation of nuclear weapons has typically been the task of nations' intelligence services. Specifically, the task of predicting the spread of nuclear weapons in the world, as opposed to predicting one country's nuclear trajectory, has mostly been undertaken by the intelligence agencies of major powers, such as the United States and Great Britain (Bollfrass 2017: 33-4). For that reason, this chapter will look into the efforts of the US intelligence community to predict the global spread of nuclear weapons.

Studying the US case as an important example, the chapter identifies a strong propensity among intelligence services to overestimate the number of countries that would acquire the bomb. It argues that this tendency reflects the way intelligence agencies deal with uncertainty. Specifically, when analysts estimate the future proliferation behaviour of states yet lack reliable intelligence on the latter's intentions - which is often the case - they place too much emphasis on states' capability to develop the bomb. This inference, in turn, favours exaggerated appraisals of whether states will actually acquire a nuclear arsenal. On the other hand, this effect vanishes once analysts have good evidence on proliferators' intentions.

Understanding how the US intelligence community overestimates proliferation risks is not only intriguing for scholars of the nuclear age, but also consequential 
for practical policy. As the chapter shows, at critical junctures in the past, when proliferation shocks vastly increased uncertainty about the future environment, US policy-makers responded to pessimistic predictions by bolstering the nonproliferation regime, thus building the pillars of today's global nuclear order.

The chapter proceeds in five steps. The first section defines proliferation and highlights five characteristics of nuclear politics and technology that make predicting states' proliferation behaviour particularly challenging. The second section describes the accuracy of US intelligence estimates of global proliferation trends. To explain how the analysts overpredicted proliferation, the third section musters evidence showing an unwarranted focus of US intelligence on capabilities, which often favours overestimates. The fourth section shows how ominous predictions informed crucial US policy initiatives that reinvigorated the nonproliferation regime. The last section puts the US track record of overprediction into perspective.

\section{The nature of the beast: the dual-use problem, ambivalence, and proliferation}

Nuclear proliferation is commonly defined as the spread of nuclear weapons to states that did not previously have them. Today, between 40 and 50 nations are considered nuclear-capable (ElBaradei 2004; Debs and Monteiro 2017: 332). Crucially, being nuclear-capable does not necessarily mean that a country possesses all the technologies and materials required for building the bomb (Sagan 2010). This latter stage of development is called nuclear latency, and Japan is often cited as the prime example of such a latent nuclear power (Fuhrmann and Tkach 2015). In contrast, nuclear-capable nations possess the industrial base, technological expertise, and economic resources that enable them to produce the technologies and materials necessary to develop nuclear arms. Hence, nuclearcapable states have the potential to become latent, but can choose not to go down this road. Two important examples of nations that are deemed nuclear-capable but do not yet possess nuclear latency are South Korea (Fitzpatrick 2016: 26-36) and Saudi Arabia (Lewis 2015).

Of the 40 to 50 nuclear-capable states, some 35 have, at one point or another, embarked upon the path leading toward nuclear weapons. However, only ten of them have acquired a nuclear arsenal. The remaining 25 or so countries have abandoned their nuclear weapons activities before building a nuclear explosive device (Müller and Schmidt 2010; Mikoyan 2012; Santoro 2017). Predicting the proliferation behaviour of the 40 to 50 capable nations has proven particularly challenging for several reasons, many of which are related to the nature of nuclear technology and the politics of proliferation.

First, since a good explanation for why such nations build nuclear weapons has proven elusive, analysts cannot accurately predict behaviour based on some observable conditions (Bell 2016). The conventional wisdom during the Cold War was that states sought a nuclear arsenal for loosely specified national security reasons. However, this simplification did not find empirical support, and 
it has been found wanting by later research (for reviews, see Sagan 1996/97; Potter and Mukhatzhanova 2008). Neither academic work nor, for all we know, research conducted within government has managed to arrive at a new consensus on the causes of proliferation, however (Chernoff 2014: 62-122). Yet in the absence of an explanation, intelligence analysts do not know which potential causal factors they should pay attention to.

Second, the dual-use character of nuclear equipment - the fact that most of the technologies and materials needed to build nuclear weapons are also useful for peaceful nuclear programmes - makes it difficult for outside analysts to discern whether a nuclear-capable state is 'really' intent on building a nuclear arsenal. In particular, it is entirely possible that nuclear facilities which were built for peaceful purposes are later converted to facilitate a nuclear weapons project. What is more, even if certain technologies were acquired with a nuclear weapons option clearly in mind, possessing them can usually easily be justified vis-à-vis the international community with their potential use in civilian applications. Notably, it is impossible to refute such false declarations through logical arguments alone - that is, without additional intelligence that persuasively documents the state's military nuclear goals (Acton 2009).

Third, complicating things further, the leaders of capable nations might not have strong and well-developed intentions in the nuclear field at all: They may cultivate a 'nuclear ambivalence' (Abraham 1999) as the dual-use nature of the infrastructure does not force them to commit their country's nuclear programme to either peaceful or military goals until very late in the process. There are thus usually mixed signals during this period, with certain domestic constituencies pushing for the bomb, while others oppose such ideas. With the political leadership undecided, foreign intelligence services cannot guess who is going to win this internal debate.

Fourth, the pervasive secrecy surrounding nuclear weapons activities makes it hard to get inside information about countries' nuclear ambitions. Proliferators have typically kept quiet about their weapons projects until after their first nuclear test; and Israel and Apartheid South Africa did not reveal any information about their nuclear ambitions even after acquiring and stockpiling weapons (Cohen and Frankel 1990). Moreover, as proliferators' understanding of technical surveillance measures, like satellite imagery, increased, they developed sophisticated concealment strategies to hide their clandestine nuclear activities (Hansen 2011: 11).

Fifth, the little information that can be acquired through nuclear espionage may not be reliable because proliferating states often attempt to deceive the outside world about their intentions (Ellis and Kiefer 2004: 87-108; Kay 1995). In addition to deception by the target, Western intelligence analysts might be fed false or biased information by liaison intelligence services that have superior access to human sources in the proliferating country, yet which may have ulterior motives (Hansen 2011: 10).

Given these five challenges, intelligence analysts focusing on nuclear proliferation often face overwhelming constraints that make their job difficult even 
under the best of circumstances. As a long-time intelligence officer commented, 'uncertainty in this subject abounds, and prediction is foolhardy' (Paul Pillar, quoted in Graham and Hansen 2009: xv). Nevertheless, as the following section chronicles, the US intelligence community has been tasked with 'mission impossible', and has tried hard to fulfil it: predicting the spread of nuclear weapons.

\section{The history of the future of proliferation: reassessing US intelligence estimates}

At the dawn of the nuclear age, US intelligence efforts to predict proliferation targeted the nuclear programmes of just a few states that were considered major enemies, such as Nazi Germany and the Soviet Union (Richelson 2006: 17-104). Only in the late 1950s did these spying efforts expand in scope to include both adversaries and allies. This expansion of the US list of nuclear espionage targets went hand-in-hand with attempts to move beyond estimates of individual nations' nuclear activities and also pay attention to worldwide proliferation trends (Burr 2013).

The global assessments came in two forms: National Intelligence Estimates (NIEs) and studies produced by the Central Intelligence Agency (CIA). As of mid-2018, 12 such US assessments of global proliferation trends, each of which typically spans some 20 pages, have been declassified. The first of these estimates was produced in 1957; the most recent declassified appraisal is from 1991. Taken together, the available assessments provide a clearer picture of how the US intelligence community saw the future of proliferation in the early and middle Cold War than in the late Cold War. Two of the 12 estimates were produced in the 1950s (NIE 1957; NIE 1958), five in the 1960s (NIE 1960; NIE 1961; NIE 1963; NIE 1964; NIE 1966), and three in the first half of the 1970s (NIE 1974; NIE 1975; CIA 1975). For the 15-year period from 1976 to 1991, a mere two appraisals of proliferation trends (NIE 1982; NIE 1991) have been declassified, albeit we do not know how many were actually written.

To gauge the performance of US intelligence in forecasting the spread of nuclear weapons, I have compared the time-bounded predictions of states' proliferation behaviour that were made in the intelligence estimates with the current scholarship's understanding (Bleek 2017, unless noted otherwise) of these nations' nuclear status in the years following the assessments. Importantly, only falsifiable statements - that a state 'will' build nuclear weapons, 'is likely to' do so, or that proliferation 'is probable' - were considered predictions. Judgements using strong estimative qualifiers - that a country 'might' or 'could' acquire the bomb, or that proliferation was 'possible' - did not qualify. Predictions relying on scenarios that failed to materialize were also not included in the analysis. Crucially, rather than merging the predictions from all NIEs and CIA studies into a single data set, I reviewed each document individually.

On balance, the 12 declassified US proliferation assessments paint a fairly bleak picture of the future nuclear landscape. In hindsight, 8 of the 12 assessments 
strongly overestimated the number of states that would pursue or acquire nuclear weapons within the estimate's timeframe (normally ten years, sometimes five). Three NIEs slightly underestimated the rate of proliferation. In one appraisal, there was no net misestimation in either direction. Not a single assessment predicted all nuclear programmes correctly.

Interestingly, while the overall propensity to overestimate seems clear, this characteristic of US proliferation assessments was not evenly distributed over time. While the early US estimates produced during the 1950s clearly overpredicted the scope of nuclear proliferation over the next decade, US nuclear intelligence during the 1960s appears more accurate in retrospect. In fact, three of the five NIEs produced during this decade slightly underestimated the future rate of proliferation. Beginning in the mid-1970s, however, US intelligence returned to its earlier alarmist tone, consistently overpredicting the spread of nuclear weapons.

The identified tendency toward overpredicting the spread of nuclear weapons dovetails nicely with other research that evaluated the forecasting performance of US intelligence agencies based on different measures and further data. Thus, a recent study that focused on country-specific intelligence estimates, as opposed to global trends (Montgomery and Mount 2014), and a survey of both US government and expert assessments (Yusuf 2009) each concluded that when it comes to predicting proliferation, overestimation is the rule and not the exception. Other influential scholarship has echoed this finding (Mueller 2010: 89-95; Gavin 2010: 17-19). However, focusing both on predicting the future and on tracking past and current nuclear activities, one recent study (Bollfrass 2017) found a much higher success rate for US assessments of worldwide proliferation.

Critics may argue that pessimistic forecasts constitute a self-defeating prophecy in that dire predictions spur determined US nonproliferation efforts that prevent more states from going nuclear, thus making the predictions appear alarmist in hindsight although they were justified at the time (Miller 2014). However, after controlling for this potential effect, my results for all the NIEs remain the same. I still find that most of the time, US intelligence overpredicted the spread of nuclear weapons. But how did the analysts arrive at their overestimates?

\section{The anatomy of alarmism: how US intelligence overestimates proliferation}

From the outside, it is almost impossible to know how US intelligence officers reach a specific judgement that is included in an NIE. While analysts at the working level are required to clarify the reasoning behind their conclusions (Fingar 2010: 80-8), most of this analytically important information is excluded from the version for the intelligence consumers - and this is usually the only document that is declassified. Consequently, researchers seeking to understand certain judgements in NIEs do not know what different pieces of 
data the analysts had at their disposal, what assumptions and analogies they used to bridge information gaps, what theories they employed to weigh the evidence, what alternative hypotheses they rejected, and what comparisons they conducted before they qualified their judgements. These specifics of intelligence officers' analytical tradecraft remain hidden from public view, and very few of the (rare) internal reviews that reveal them have been declassified.

Given this fundamental lack of transparency, outsiders can only theorize rather than describe and explain - how intelligence agencies reach their judgements on a specific issue. Subsequently, one can only examine if the limited available evidence fits the proposed argument. Therefore, in this section I offer such a theory to account for the US intelligence community's overprediction of proliferation.

\section{A capability-based theory of proliferation alarmism}

To account for the observed overprediction, the theory proposed here argues that when US intelligence agencies estimated states' future proliferation behaviour, they placed too much emphasis on nations' technological capabilities. While technology is essential for proliferation, an excessive focus on such factors leads analysts to overestimate foreign nuclear programmes. This happens through two mechanisms. First, inferring future nuclear behaviour from capability alone ignores proliferation intent and resolve, thus inflating the number of countries seeking a nuclear arsenal (Hymans 2006; Narang 2016/17). Second, concentrating on facilities and equipment neglects the veritable challenge of successfully running a nuclear weapons programme (which is more than the sum of its parts), thereby unduly compressing proliferation timelines (Hymans 2012; Sagan 2010).

Interestingly, the US intelligence community itself apparently tried to avoid relying too much on technological factors in its appraisals of states' future proliferation behaviour. This motivation manifested itself in two ways: First, all assessments explicitly distinguished between nations' 'capabilities' in the nuclear realm, which the NIEs reported first, and the 'probable courses of action' of these states, which were estimated in a subsequent section (e.g. NIE 1957: 2, 5).

Second, in addition to differentiating between capability and intent, US intelligence estimates from 1960 on have stressed at the outset that a state's decision to develop a nuclear arsenal would reflect a calculation of 'a complex of economic, political, military, and psychological considerations' that would differ in each case (NIE 1960: 4). By conceding the importance of those factors that shape a country's willingness and determination to pursue or renounce the bomb, the analysts again seem to have sought to ensure that their predictions would not be dominated by appraisals of technical capabilities, but would pay serious attention to the demand-side variables that strongly influence whether states go or not go nuclear.

Importantly, the theory developed here argues that US intelligence analysts frequently placed an excessive focus on the technical side of the proliferation 
equation despite the agencies' obvious motivation to produce balanced assessments. Specifically, the theory contends that the unwarranted reliance on capabilities typically resulted from a lack of good evidence on the target state's intentions and resolve to obtain a nuclear arsenal. Without reliable evidence on whether a government actually wanted the bomb, and what political price it was willing to pay to get it, intelligence officers fell back on what they had, using the available information about that state's facilities and technological prowess as a proxy for intent. Such inferences, however, blur the analytical distinction between the two domains. On the other hand, when US intelligence possessed credible evidence on proliferation intent, it placed greater inferential weight on this information than on what a state could do given its capabilities. As a result, overestimates became less likely.

\section{Overall trends: abundant supply, few disincentives}

In the estimates, the capabilities-centric bias of US nuclear intelligence manifested itself in two ways. One of them concerned the detailed survey of overall supply-side trends that each of the NIEs opened with before looking at individual nations. The usual thrust of this section was that the technologies, materials, and know-how required to develop nuclear weapons were becoming available to ever more states, and that the economic costs of building a small arsenal continued to decrease. Importantly, this section often set the tone for the rest of the estimate. For example, the pessimistic 1958 NIE opened with the gloomy finding that 'a large number' of states 'could produce at least a few' crude nuclear bombs within the next decade (NIE 1958: 1). Since the advent of gas centrifuge technology, which is easier to conceal than other methods of producing fissile material for weapons, the capabilities-centric introduction also included a caution that 'nations could develop nuclear weapons clandestinely, right up to the time of the first test' (NIE 1964: 5). Because such deception would further diminish the chances that intelligence could provide effective warning, this caveat gave the impression that the 'true' proliferation picture was even bleaker than the NIEs suggested.

In contrast, the NIEs' corresponding survey of overall demand-side aspects, and particularly the part on disincentives to acquiring the bomb, was always much shorter and less substantive. Beyond shallow references to the high economic costs of large and sophisticated nuclear forces (as opposed to small arsenals) and the risk of public opposition, the typical thrust of this analysis was that 'it's complicated' and, therefore, the demand-side calculation would differ in each case. Remarkably, US intelligence did not amend the NIEs' list of structural disincentives even after the 1968 Nuclear Nonproliferation Treaty (NPT) had legally banned the development of nuclear arms by additional states and the Nuclear Suppliers Group (NSG) guidelines of 1975 had stigmatized trade in weapons-sensitive technologies, thus transforming the context of future proliferation decision-making.

Written by an outside observer, the analysis above can merely suggest a mismatch between US intelligence's grasp of supply-side trends and demand-side 
dynamics. This interpretation receives powerful confirmation, however, through an inside assessment by the US National Intelligence Council (NIC), a highlevel panel that must approve all NIEs. Reexamining in 1985 why the recent NIEs had arrived at such massive overestimates of proliferation, the NIC concluded that the appraisals had been 'based on too narrow a perception of the process by which the spread of a nuclear explosive capability comes about'. In particular, while the NIEs generally conceded the key role of demand-side factors, according to the NIC review,

[...] the analysts found it extremely difficult to specify what those nontechnical factors were and how they would affect nuclear decision-making. Consequently, their predictions tended to be driven by straight-line projections of such matters as how soon a country could produce sufficient fissile material for an explosion, given its recent pace of technological acquisition. These projections gave an air of technological inevitability to the proliferation process, implying that, if a country acquired more and more of the technical ingredients that go into making a nuclear device, the decision to consummate that option would become increasingly easier to make and, in fact, would eventually be made.

(NIC 1985: 9)

To sum up, as US analysts struggled to understand demand-side dynamics, they focused on capability, effectively using it as a proxy for proliferation intent.

\section{Country-specific estimates: uncertainty privileges capability}

Beyond the global trends section, the emphasis on capabilities was also apparent in the NIEs' analysis of specific countries of proliferation concern. While the NIEs - at least until 1975 (see below) - addressed both a state's capability and proliferation intent, it seems that judgements about the latter were rarely informed by high-quality intelligence, such as insights from credible human sources. Rather, the officers had to rely on open sources and their own abstract beliefs about how the (nuclear) world works, to infer a state's willingness to develop the bomb. Facing such uncertainty, US analysts again let 'hard facts' about capabilities drive their predictions.

\section{The 1950s}

An internal review of the 1958 NIE - which, in retrospect, had strongly overpredicted proliferation - is fully in line with this interpretation. It complained that, 'With respect to the political factors in the possible decisions of fourth countries to initiate nuclear weapons programs, we believe that the field reporting could be more full than it now is' (US Intelligence Board 1958: 2, italics in the original). In other words, when they were producing an NIE that massively overestimated future proliferation, US analysts had lacked the raw data necessary to 
make informed judgements about nations' intent and resolve to obtain nuclear weapons.

\section{The 1960s}

In response to the 1958 reappraisal, the State Department requested concerned diplomatic missions to step up their intelligence collection and reporting on the 'political aspects' shaping the demand-side of nuclear choices (Department of State 1958). Fortunately for US spies, among the states of proliferation concern in the 1950s and 1960s, most were Western industrialized nations and US allies. The large American presence in these countries and the dense web of personal relationships naturally facilitated US intelligence collection, notably from human sources. Perhaps as a result, judgements about the nuclear intentions of these Western targets improved markedly in the 1960s, and overestimates of their future proliferation behaviour almost disappeared despite the continued build-up of their capability to develop the bomb. For instance, unlike previous estimates, the 1960 NIE confidently reported about West Germany and Sweden's intentions that neither of the two governments had plans to develop nuclear weapons and that both were therefore unlikely to do so (NIE 1960). Their technical ability to build an arsenal ceased to be the dominant indicator.

Consistent with this pattern of reduced uncertainty about Western nuclear ambitions, the one state whose programme was repeatedly overestimated during the 1960s - India - was a non-Western developing country that US spies found hard to penetrate. While Washington was well informed about India's advanced nuclear facilities, the same was not true for India's lacking intent to deploy an arsenal. Yet although they knew almost nothing about Indian leaders' proliferation calculus, the authors of the 1964 and 1966 NIEs still predicted that the country would soon build the bomb. Tellingly, to support this conclusion, neither estimate pointed to any actual tectonic shifts in Delhi. Both just referred to 'internal pressures' that 'will probably rise' over the coming years and then somehow push India over the weapons threshold (NIE 1964: 8). While confirmation is elusive, the fact that, technically, India was merely 'a screwdriver's turn' away from the bomb apparently made US analysts bet that leaders in Delhi would soon want nuclear weapons, although they had zero evidence of such intentions.

\section{The 1970s and after}

Given how US intelligence had overestimated India in the 1960s, regional trends in subsequent decades promised to make the task of predicting proliferation even more daunting. Since the 1970s, the countries ending up on Washington's list of states of proliferation concern were overwhelmingly developing states in the Middle East, Asia, and Latin America. Collecting intelligence, notably from human sources, was more challenging in these countries as the United States 
typically had no troops there, nor close political ties to the regimes. With only a rudimentary grasp of their targets' nuclear intentions, US analysts again seemed to rely too heavily on technical indicators to predict behaviour.

This verdict applies, for instance, to the estimate on Taiwan in 1974, although the latter was then still a US treaty ally. Even as US analysts had 'no reliable information' about Taiwan's nuclear plans, they still asserted that it would 'probably' build the bomb by the mid-1980s (NIE 1974: 28-9). The logic behind this prediction likely included the technological determinism that is reflected in the NIE's account of Taiwan's proliferation motives until 1974. According to that appraisal, 'most likely [...] the program gathered momentum as the military-scientific bureaucracy expanded to staff the effort, and feasibility became an independent justification of sorts' (NIE 1974: 28). Hence, US intelligence believed that, at least to some extent, growing capability had been driving Taipei's willingness to proliferate. Absent reliable evidence on intent, this assumption about the influence of technical progress may have shaped the US prediction of Taiwan's future trajectory as well.

Notably, the US intelligence establishment knew that its technology-centric nuclear expertise presented a problem. In 1976, a review by intelligence community staff concluded that only its grasp of the technical aspects of proliferation was 'satisfactory', and that an improved overall performance required analysts to achieve 'greater political, economic, and military integration with the technical aspects' (CIA 1977: 9). Rather than paying more attention to such demand-side factors, however, the NIEs produced after 1974 doubled down on states' capabilities. Specifically, the definition across the estimates of what constitutes nuclear proliferation began to shift, a change that was later criticized by the intelligence establishment because it was never clearly stated in the assessments (NIC 1985: 7). Thus, while the 1974 estimate, like all previous NIEs, had studied who would acquire a nuclear weapon capability, the update produced the following year broadened the scope. It was explicitly written to provide the earliest dates for when countries could build a nuclear explosive device, as India had done in 1974 - a step well below the important weaponization threshold (NIE 1975: 1). Expanding the definition of proliferation even further, the 1982 NIE concentrated on the spread of sensitive nuclear facilities that states might use to develop a nuclear explosive (or weapons) capability, but which do not individually represent that more disturbing capability.

Absent an explanation for why a broader definition was appropriate, and what it meant for the predictions made prior to 1975, the shifting understanding of proliferation raised grave questions about the comparability of results across time. (To facilitate such comparability, this chapter has considered only those predictions in NIEs that included an expectation of nuclear weapons intent.) More important for the inferences made by US intelligence, however, the broadened definition further incentivized the development of technical competence at the expense of expertise on demand-side aspects. The task of predicting which countries will build sensitive facilities - without having to estimate if they will use the facilities for weapons purposes - can be fulfilled by simply monitoring 
the technical progress of their civilian nuclear research programmes. Reading these states' intentions is not necessary to this end. As a result, engaging in the difficult business of discerning nuclear intentions became even less attractive for intelligence officers. In fact, from the analysts' viewpoint, the increased emphasis on technical aspects made the job of forecasting proliferation more straightforward: Hidden in the text of one NIE, they conceded that 'the evolution of nuclear capabilities' was easy to predict because it '[c]an be estimated fairly well and is not susceptible to rapid fluctuations' (NIE 1982: 14).

Even as nuclear weapons proliferation ceased to be the principal focus of US estimates after 1974, the agencies continued to offer some judgements on such ambitions. Reflecting the growing neglect of political analysis, US intelligence's detailed picture of a state's nuclear facilities and equipment then sometimes appeared to make the analysts overconfident as to what that state's proliferation intentions must be. The judgement made in 1982 that Argentina was constructing a facility that 'is useful, in practical terms, only for manufacturing [nuclear] explosive devices', when in fact that nation never sought such explosives, is a case in point (NIE 1982: 21). As far as the analysts were concerned, however, drawing on capability to infer intent and predict proliferation behaviour was good enough since tracking nuclear facilities 'offers insights into past policy decisions, [which are] sometimes the only reliable evidence concerning current policies' (NIE 1982: 14).

None of the above is to suggest that the intelligence officials responsible for the US assessments did not do reasonably well in predicting the nuclear future. It is clearly part of the job of intelligence analysts to bridge information gaps through analogies and assumptions about unknowns, including other governments' intentions and their determination to achieve specific goals (Fingar 2010: 72). The point made here is just that US analysts consistently erred toward overestimation because they privileged one specific indicator: states' capability to build the bomb. This inquiry into the mechanisms of US overestimation is of more than academic interest because, as the following section illustrates, overpredicting global proliferation can have lasting real-world consequences.

\section{The consequences of alarmism: the nonproliferation regime as we know it}

The envisioned future of increasing proliferation was a key driver for the creation and the subsequent strengthening of today's global nuclear order. Specifically, pessimistic forecasts that nuclear weapons were about to spread to ever more states played a crucial role in the tightening of US nuclear nonproliferation policy in the mid-1960s and the mid-1970s (Miller 2018). Importantly, these strengthened US policies were instrumental in building two central pillars of the international nonproliferation regime: the NPT and the NSG. However, although the predictions triggering these efforts originated in the US government, it was expert panels and agencies outside the intelligence community who produced these estimates. 


\section{The Gilpatric Report and the road to the NPT}

The changes to US policy made in the mid-1960s concerned the universal application of strict nonproliferation standards to both adversaries and allies of the United States (Gavin 2004/05). Though containing proliferation has been a consistent goal of US policy throughout the nuclear age (Gavin 2015), until 1965 Washington had not always accorded nonproliferation a high priority in relations with friendly regimes (Trachtenberg 1999). This selective enforcement was abandoned in response to alarming predictions that the spread of nuclear weapons was about to accelerate. Specifically, several US studies anticipated that Communist China's first nuclear weapon test in October 1964 would trigger nuclear domino effects. In this view, proliferation in response to China by nations friendly to the United States, such as Japan and India, would lead even more, and potentially adversarial, countries, to embark upon the path toward a nuclear arsenal (Miller 2018).

One such warning was issued by the US Arms Control and Disarmament Agency (FRUS 1964-1968a). The greatest impact on subsequent US policy, though, was a 1965 report produced for President Lyndon Johnson by a blueribbon panel chaired by former Deputy Secretary of Defense Roswell Gilpatric. In their report, the members of this Gilpatric Committee ominously predicted that once India and Japan would react to Chinese proliferation with their own bomb projects, 'we do not believe that the spread of nuclear weapons would or could be stopped there'. In the end, Egypt, Israel, Pakistan, West Germany, and several others would surely follow suit to join the nuclear weapons club (FRUS 1964-1968b: 174).

In hindsight, this projection seems excessively pessimistic. Whether it was realistic or not, however, the Gilpatric Committee Report apparently had a decisive influence on official US nonproliferation policy. Embracing the report's appraisal of imminent danger, President Johnson, after some delay, authorized a comprehensive programme that intensified US efforts to combat proliferation across-the board, and which reflected the basic gist of the Gilpatric Committee's recommendations (Brands 2006). Chief among these initiatives was the decision to give priority to reaching a broad nonproliferation agreement with the Soviet Union, even if this meant burying the idea of joint nuclear forces that some European allies were then strongly interested in - a sharp departure from previous US policy that eventually led to the NPT (Brands 2007; Popp 2017).

Interestingly, the Gilpatric Report's influential premise, that many countries would soon acquire a nuclear arsenal if US policies remained unchanged, was strongly at odds with the intelligence community's views at the time. The 1964 NIE, which was completed days after China's first nuclear test, only slightly overpredicted global proliferation. Its authors expected, erroneously, that India would soon weaponize its nuclear programme but did not feel comfortable making any other unequivocal predictions of proliferation decisions (NIE 1964). Moreover, a briefing paper that the CIA prepared for the Gilpatric Committee's deliberations also predicted a fairly benign future nuclear landscape, going even 
further than the NIE by judging that 'Israel probably has decided not to build nuclear weapons' (CIA 1964: 10). US intelligence thus painted a picture of global nuclear trends that was not nearly as dark as the Gilpatric Report's vision of impending proliferation doom. The fact that both the committee and US policy-makers ignored these intelligence judgements gives rise to important questions, such as Who gets heard, and Which prediction is acted upon. Unfortunately, however, the reasons why the intelligence community failed to have an impact on US policy in this particular case are not known.

\section{The Under Secretaries' Report, the Lord Paper, and the NSG}

In the mid-1970s, US nonproliferation policy was strengthened further as a result of several major advances (Miller 2018: 74-90). Among these initiatives, however, only the Ford administration's push for the NSG can be directly linked to predictions of proliferation. Specifically, two studies produced in reaction to India's first nuclear test in May 1974 offered a gloomy picture of the event's impact on the further spread of nuclear arms.

The first estimate ringing the alarm bell was a draft paper on US nonproliferation policy prepared in June 1974 by the National Security Council's Under Secretaries Committee. The study estimated that the consequence of the Indian nuclear test "could be a sequential or "chain reaction" with perhaps as many as ten additional states acquiring some nuclear weapons capability' (FRUS 1969-1976a: 132). The State Department's director of policy planning, Winston Lord, produced another paper for Secretary Henry Kissinger. Like the Under Secretaries' Report, the Lord Paper worried that India's test 'could lead others to acquire independent nuclear explosives capabilities in a "chain reaction" effect' (Department of State 1974: 1). Notably, although both studies argued only that India's test could trigger domino effects, and thus did not explicitly predict further proliferation, US policy-makers evidently understood the phrasings as firm predictions. In meetings, Lord asserted that concerning proliferation, 'if we don't do anything, certainly the situation is going to get much worse, and the pace will pick up, and the spread will be all but inevitable'. Even firmer in his view, Kissinger projected that no matter what Washington did, additional proliferation was 'probably inevitable' (FRUS 1969-1976b: 193).

Like the Gilpatric Report's predictions, the estimates from the 1970s - that over the next years, proliferation would be 'much worse' than before and involve 'as many as ten additional states' - appear exaggerated in hindsight. Nevertheless, they apparently shaped US nonproliferation policy to a significant degree (Miller 2018: 75-9). Buying into the Under Secretaries' Report and the Lord Paper's nuclear domino scenarios, US policy-makers embraced the reports' recommendation to curb further proliferation by seeking consultations among the major supplier states on common rules that ensure that nuclear exports would not contribute to nuclear weapons programmes. Out of this 1974 US initiative grew intense secret negotiations among seven advanced nuclear industrial powers that quickly led to what later became known as the NSG (Burr 2014). 
Interestingly, unlike in the previous decade, in the mid-1970s the influential government studies on proliferation were in line with how US intelligence viewed the future spread of nuclear arsenals. The authors of the 1974 NIE, which was completed in December 1974, were just as concerned as Winston Lord and the members of the Under Secretaries' Committee, expecting that several more states would soon develop a nuclear arsenal (NIE 1974). It is not clear, however, to what extent the authors of the two papers had consulted with US intelligence for their projections.

\section{Instead of a conclusion: putting US overprediction into perspective}

Drawing on the declassified record of global proliferation assessments, this chapter has found that the US intelligence community has never been fully correct in predicting the spread of nuclear weapons, and it has typically erred in the direction of overestimation. This finding needs to be put into perspective. Most obviously, it bears repeating that owing to the dual-use nature of nuclear technology and the secretive character of nuclear politics, intelligence analysts working on proliferation are being asked to make predictions against an exceptionally hard target.

Moreover, and relatedly, intelligence analysts are fully aware of the perils of predicting others' behaviour under great uncertainty. Unfortunately, though, the intelligence community's principal customers - policy-makers - favour appraisals exhibiting certainty, not cautious and conditional estimates. Therefore, while intelligence officers prefer qualifying language and loathe making firm predictions, the desire to provide analyses that policy-makers find useful naturally pushes intelligence analysts toward stripping their judgements of indications of doubt and making unequivocal predictive claims (Rovner 2010: 12, 24). In this setting, it is not surprising that intelligence analysts attempted to predict the future nuclear landscape, nor that their predictions repeatedly turned out to be wrong.

Finally, the fact that gloomy projections have twice spurred US initiatives that bolstered international nonproliferation efforts does not imply that alarmist proliferation estimates will always have such positive effects. The flawed US intelligence on Iraq's weapons of mass destruction, and the key role it played on the road to the 2003 war (Jervis 2006), is a forceful reminder that exaggerated proliferation estimates may come at a very high price. No less important, however, it is policy-makers, not intelligence analysts, who bear ultimate responsibility for nonproliferation policy in general and decisions for war in particular: NIEs do not force the policy-maker's hand when the latter responds to a threat assessment.

\section{Note}

1 The author would like to thank Alex Bollfrass, Myriam Dunn Cavelty, Liviu Horovitz, Ulla Jasper, Oliver Meier, Oliver Thränert, and Andreas Wenger for helpful comments. 


\section{References}

Abraham, I. (1999) The Making of the Indian Atomic Bomb: Science, Secrecy, and the Postcolonial State, London: Zed Books.

Acton, J. M. (2009) 'The Problem with Nuclear Mind Reading', Survival 51(1): 119-42.

Bell, M. S. (2015) 'Beyond Emboldenment: How Acquiring Nuclear Weapons Can Change Foreign Policy', International Security 40(1): 87-119.

Bell, M. S. (2016) 'Examining Explanations for Nuclear Proliferation', International Studies Quarterly 60(3): 520-9.

Bleek, P. C. (2017) When Did (and Didn't) States Proliferate? Chronicling the Spread of Nuclear Weapons, Cambridge, MA: Harvard Kennedy School/Monterey, CA: James Martin Center for Nonproliferation Studies.

Bollfrass, A. K. (2017) The Half-Lives of Others: Explaining the Accuracy of Nuclear Proliferation Assessments, Doctorate thesis, Princeton University.

Brands, H. (2006) 'Rethinking Nonproliferation: LBJ, the Gilpatric Committee, and US National Security Policy', Journal of Cold War Studies 8(2): 83-113.

Brands, H. (2007) 'Nonproliferation and the Dynamics of the Middle Cold War: The Superpowers, the MLF, and the NPT', Cold War History 7(3): 389-423.

Burr, W. (2005) 'National Intelligence Estimates of the Nuclear Proliferation Problem: The First Ten Years, 1957-1967', National Security Archive Electronic Briefing Book No. 155. Online. Available: https://nsarchive2.gwu.edu//NSAEBB/NSAEBB155/ index.htm (accessed 7 March 2019).

Burr, W. (2013) 'Nuclear Proliferation Intelligence, 1966-1991: China May Have Helped Pakistan Nuclear Weapons Design, Newly Declassified Intelligence Indicates', National Security Archive Electronic Briefing Book No. 423. Online. Available: https:// nsarchive2.gwu.edu/nukevault/ebb423 (accessed 7 March 2019).

Burr, W. (2014) 'A Scheme of "Control": The United States and the Origins of the Nuclear Suppliers Group, 1974-1976', International History Review 36(2): 252-76.

Chernoff, F. C. (2014) Explanation and Progress in Security Studies: Bridging Theoretical Divides in International Relations, Stanford, CA: Stanford University Press.

CIA (1964) 'Memorandum: Nuclear Weapons Programs around the World', National Security Archive Electronic Briefing Book No. 155. Online. Available: https://nsarchive2. gwu.edu//NSAEBB/NSAEBB155/prolif-10.pdf (accessed 7 March 2019).

CIA (1975) 'Managing Nuclear Proliferation: The Politics of Limited Choice', Central Intelligence Agency Research Study OPR 408, National Security Archive Electronic Briefing Book No. 155. Online. Available: https://nsarchive2.gwu.edu//NSAEBB/ NSAEBB155/prolif-15.pdf (accessed 7 March 2019).

CIA (1977) 'A Review of Nuclear Proliferation Intelligence Activities and Developments', DCI/IC 77-2500, CIA Electronic Reading Room. Online. Available: www.cia. gov/library/readingroom/docs/CIA-RDP83M00171R000500150006-1.pdf (accessed 7 March 2019).

Cohen, A. and Frankel, B. (1990) 'Opaque Nuclear Proliferation', Journal of Strategic Studies 13(3): 14-44.

Debs, A. and Monteiro, N. P. (2017) 'Conflict and Cooperation on Nuclear Nonproliferation', Annual Reviews of Political Science 20: 331-49.

Department of State (1958) 'Development of Nuclear Weapons Capabilities by "Fourth Powers": Political Aspects, December 3, 1958', National Security Archive Electronic Briefing Book No. 155. Online. Available: https://nsarchive2.gwu.edu//NSAEBB/NSAEB B155/prolif-4c.pdf (accessed 7 March 2019). 
Department of State (1974) 'Discussion Paper on US Nonproliferation Policy, Enclosed with Briefing Memorandum to Secretary of State Kissinger from Policy Planning Staff Director Winston Lord, “Analytical Staff Meeting”, July 11, 1974', National Security Archive Electronic Briefing Book No. 467. Online. Available: https://nsarchive2.gwu.edu/ nukevault/ebb467/docs/doc\%205\%207-11-74\%20discussion \%20paper\%20for\%20 staff\%20meeting.pdf (accessed 7 March 2019).

ElBaradei, M. (2004) Statement to the Forty-Eighth Regular Session of the IAEA General Conference 2004, International Atomic Energy Agency (IAEA), 20 September. Online. Available: www.iaea.org/newscenter/statements/statement-forty-eighth-regularsession-iaea-general-conference-2004 (accessed 7 March 2019).

Ellis, J. D. and Kiefer, G. D. (2004) Combating Proliferation: Strategic Intelligence and Security Policy, Baltimore, MD: Johns Hopkins University Press.

Fingar, T. (2010) Reducing Uncertainty: Intelligence Analysis and National Security, Stanford, CA: Stanford University Press.

Fitzpatrick, M. (2016) Asia's Latent Nuclear Powers: Japan, South Korea, and Taiwan, New York: Routledge.

FRUS (1964-1968a) 'Draft Position Paper, August 14, 1964', in E. Gerakas, D. S. Patterson and C. B. Yee (eds) Foreign Relations of the United States, 1964-1968, Volume XI: Arms Control and Disarmament, Washington, DC: US Government Printing Office, 97-110.

FRUS (1964-1968b) 'Report by the Committee on Nuclear Proliferation, January 21, 1965', in E. Gerakas, D. S. Patterson and C. B. Yee (eds) Foreign Relations of the United States, 1964-1968, Volume XI: Arms Control and Disarmament, Washington, DC: US Government Printing Office, 173-82.

FRUS (1969-1976a) 'Paper Prepared by the NSC Under Secretaries Committee, June 21, 1974', in K. L. Ahlberg, B. S. Kim and C. Tudda (eds) Foreign Relations of the United States, 1969-1976, Volume E-14, Part 2: Documents on Arms Control and Nonproliferation, 1973-1976, Washington, DC: US Government Printing Office, 129-44.

FRUS (1969-1976b) 'Minutes of Secretary of State Kissinger's Analytical Staff Meeting, July 12, 1974', in K. L. Ahlberg, B. S. Kim and C. Tudda (eds) Foreign Relations of the United States, 1969-1976, Volume E-14, Part 2: Documents on Arms Control and Nonproliferation, 1973-1976, Washington, DC: US Government Printing Office, 191-207.

Fuhrmann, M. and Tkach, B. (2015) 'Almost Nuclear: Introducing the Nuclear Latency Dataset', Conflict Management and Peace Science 32(4): 443-61.

Gavin, F. J. (2004/05) 'Blasts from the Past: Proliferation Lessons from the 1960s', International Security 29(3): 100-35.

Gavin, F. J. (2010) 'Same as It Ever Was: Nuclear Alarmism, Proliferation, and the Cold War', International Security 34(3): 7-37.

Gavin, F. J. (2015) 'Strategies of Inhibition: US Grand Strategy, the Nuclear Revolution, and Nonproliferation', International Security 40(1): 9-46.

Graham, T. Jr. and Hansen, K. A. (2009) Preventing Catastrophe: The Use and Misuse of Intelligence in Efforts to Halt the Proliferation of Weapons of Mass Destruction, Stanford, CA: Stanford University Press.

Hansen, K. A. (2011) Intelligence and Nuclear Proliferation: Lessons Learned, Proliferation Papers No. 38, Paris: IFRI.

Hymans, J. E. C. (2006) The Psychology of Nuclear Proliferation: Identity, Emotions, and Foreign Policy, New York: Cambridge University Press. 
Hymans, J. E. C. (2012) Achieving Nuclear Ambitions: Scientists, Politicians, and Nuclear Proliferation, New York: Cambridge University Press.

Jervis, R. (2006) 'Reports, Politics, and Intelligence Failures: The Case of Iraq', Journal of Strategic Studies 29(1): 3-52.

Kay, D. A. (1995) 'Denial and Deception Practices of WMD Proliferators: Iraq and Beyond', Washington Quarterly 18(1): 85-105.

Lewis, J. (2015) 'Sorry, Fareed: Saudi Arabia Can Build a Bomb Any Damn Time It Wants to', Foreign Policy, 12 June. Online. Available: http://foreignpolicy.com/ 2015/06/12/sorry-fareed-saudi-arabia-can-build-a-bomb-any-damn-time-it-wants-to (accessed 7 March 2019).

Maddock, S. J. (2010) Nuclear Apartheid: The Quest for American Nuclear Superiority from World War II to the Present, Chapel Hill, NC: University of North Carolina Press.

Mikoyan, S. (2012) The Soviet Cuban Missile Crisis: Castro, Mikoyan, Kennedy, Khrushchev, and the Missiles of November, ed. by Svetlana Savranskaya, Washington, DC: Woodrow Wilson Center Press.

Miller, N. L. (2014) 'Nuclear Dominoes: A Self-Defeating Prophecy?', Security Studies 23(1): 33-73.

Miller, N. L. (2018) Stopping the Bomb: The Sources and Effectiveness of US Nonproliferation Policy, Ithaca, NY: Cornell University Press.

Montgomery, A. H. and Mount, A. (2014) 'Misestimation: Explaining US Failures to Predict Nuclear Weapons Programs', Intelligence and National Security 29(3): 357-86.

Mueller, J. (2010) Atomic Obsession: Nuclear Alarmism from Hiroshima to Al-Qaeda, New York: Oxford University Press.

Müller, H. and Schmidt, A. (2010) 'The Little-Known Story of Deproliferation: Why States Give Up Nuclear Weapons Activities', in W. C. Potter and G. Mukhatzhanova (eds) Forecasting Nuclear Proliferation in the 21st Century 1: The Role of Theory, Stanford, CA: Stanford University Press, 124-58.

Narang, V. (2016/17) 'Strategies of Nuclear Proliferation: How States Pursue the Bomb', International Security 41(3): 110-50.

NIC (National Intelligence Council) (1985) 'The Dynamics of Nuclear Proliferation: Balance of Incentives and Constraints', NIC Memorandum 85-10001, National Security Archive Electronic Briefing Book No. 451. Online. Available: https://nsarchive2. gwu.edu/nukevault/ebb451/docs/8.pdf (accessed 7 March 2019).

NIE (1957) 'Nuclear Weapons Production in Fourth Countries: Likelihood and Consequences', National Intelligence Estimate 100-6-57, National Security Archive Electronic Briefing Book No. 155. Online. Available: https://nsarchive2.gwu.edu// NSAEBB/NSAEBB155/prolif-2.pdf (accessed 7 March 2019).

NIE (1958) 'Development of Nuclear Capabilities by Fourth Countries: Likelihood and Consequences', National Intelligence Estimate 100-2-58, National Security Archive Electronic Briefing Book No. 155. Online. Available: https://nsarchive2.gwu.edu// NSAEBB/NSAEBB155/prolif-3a.pdf (accessed 7 March 2019).

NIE (1960) 'Likelihood and Consequences of the Development of Nuclear Capabilities by Additional Countries', National Intelligence Estimate 100-4-60, National Security Archive Electronic Briefing Book No. 155. Online. Available: https://nsarchive2.gwu. edu//NSAEBB/NSAEBB155/prolif-5.pdf (accessed 7 March 2019).

NIE (1961) 'Nuclear Weapons and Delivery Capabilities of Free World Countries Other than the US and UK', National Intelligence Estimate 4-3-61, National Security 
Archive Electronic Briefing Book No. 155. Online. Available: https://nsarchive2.gwu. edu/NSAEBB/NSAEBB155/prolif-6b.pdf (accessed 7 March 2019).

NIE (1963) 'Likelihood and Consequences of a Proliferation of Nuclear Weapons Systems', National Intelligence Estimate 4-63, National Security Archive Electronic Briefing Book No. 155. Online. Available: https://nsarchive2.gwu.edu//NSAEBB/NSAE BB155/prolif-8.pdf (accessed 7 March 2019).

NIE (1964) 'Prospects for a Proliferation of Nuclear Weapons over the Next Decade', National Intelligence Estimate 4-2-64, National Security Archive Electronic Briefing Book No. 155. Online. Available: https://nsarchive2.gwu.edu//NSAEBB/NSAEBB155/ prolif-9.pdf (accessed 7 March 2019).

NIE (1966) 'The Likelihood of Further Nuclear Proliferation', National Intelligence Estimate 4-66, National Security Archive Electronic Briefing Book No. 423. Online. Available: https://nsarchive2.gwu.edu/nukevault/ebb423/docs/1.\%201966\%20NIE.pdf (accessed 7 March 2019).

NIE (1974) 'Prospects for Further Proliferation of Nuclear Weapons', Special National Intelligence Estimate 4-1-74, National Security Archive Electronic Briefing Book No. 240. Online. Available: https://nsarchive2.gwu.edu/NSAEBB/NSAEBB240/snie.pdf (accessed 7 March 2019).

NIE (1975) 'Memorandum to Holders of Special National Intelligence Estimate 4-1-74: Prospects for Further Proliferation of Nuclear Weapons', Wilson Center Digital Archive. Online. Available: http://digitalarchive.wilsoncenter.org/document/121391 (accessed 7 March 2019).

NIE (1982) 'Nuclear Proliferation Trends through 1987', National Intelligence Estimate 4-82, National Security Archive Electronic Briefing Book No. 423. Online. Available: https://nsarchive2.gwu.edu/nukevault/ebb423/docs/4.\%20\%20nuke\%20prolif\%20 trends\%20thru\%2087.pdf (accessed 7 March 2019).

NIE (1991) 'Prospects for Special Weapons Proliferation and Control', National Intelligence Estimate 5-91, National Security Archive Electronic Briefing Book No. 423. Online. Available: https://nsarchive2.gwu.edu/nukevault/ebb423/docs/11.\%20special\% 20weapons.pdf (accessed 7 March 2019).

Popp, R. (2017) 'The Long Road to the NPT: From Superpower Collusion to Global Compromise', in R. Popp, L. Horovitz and A. Wenger (eds) Negotiating the Nuclear Nonproliferation Treaty: Origins of the Nuclear Order, London: Routledge, $9-35$.

Potter, W. C. and Mukhatzhanova, G. (2008) 'Divining Nuclear Intentions: A Review Essay', International Security 33(1): 139-69.

Richelson, J. T. (2006) Spying on the Bomb: American Nuclear Intelligence from Nazi Germany to Iran and North Korea, New York: W. W. Norton.

Rovner, J. (2010) Fixing the Facts: National Security and the Politics of Intelligence, Ithaca, NY: Cornell University Press.

Sagan, S. D. (1996/97) 'Why do States Build Nuclear Weapons: Three Models in Search of a Bomb', International Security 21(3): 54-86.

Sagan, S. D. (2010) 'Nuclear Latency and Nuclear Proliferation', in W. C. Potter and G. Mukhatzhanova (eds) Forecasting Nuclear Proliferation in the 21st Century 1: The Role of Theory, Stanford, CA: Stanford University Press, 80-101.

Santoro, D. (2017) Myanmar: A Nonproliferation Success Story, Canberra: Australian Strategic Policy Institute.

Trachtenberg, M. (1999) A Constructed Peace: The Making of the European Settlement, 1945-1963, Princeton, NJ: Princeton University Press. 


\section{J. Schneider}

US Intelligence Board (1958) 'Post-Mortem on NIE 100-2-58: Development of Nuclear Capabilities by Fourth Countries: Likelihood and Consequences, dated 1 July 1958', National Security Archive Electronic Briefing Book No. 155. Online. Available: https://nsarchive2.gwu.edu//NSAEBB/NSAEBB155/prolif-4c.pdf (accessed 7 March 2019).

Yusuf, M. (2009) Predicting Proliferation: The History of the Future of Nuclear Weapons, Policy Paper No. 11, Washington, DC: Brookings Institution Press. 